\title{
De omrekening van deel- nemingen in vreemde valuta naar rapporteringvaluta
}

Prof. Dr. H.P.A.J. Langendijk en S. Bissessur

\section{Inleiding}

In dit artikel wordt ingegaan op de huidige wet- en regelgeving met betrekking tot de omrekening van deelnemingen luidende in vreemde valuta naar de rapporteringvaluta in Nederland (Burgerlijk Wetboek (BW) Titel 9) en Raad voor de Jaarverslaggeving (RJ) 120, par. 9), International Accounting Standard (IAS) 21 van het International Standards Committee (IASC) en de Verenigde Staten (VS) (Financial Accounting Statement (FAS) 52) van het Financial Accounting Standards Board (FASB).

Voorts wordt verslag gedaan van een beperkt descriptief onderzoek naar de verslaggevingpraktijk met betrekking tot de omrekening van deelnemingen luidende in vreemde valuta naar de rapporteringvaluta. Hiertoe zijn de jaarrapporten van 25 Amsterdam Exchanges (AEX)-ondernemingen, 25 grote ondernemingen die IASC-regels toepassen, alsmede de jaarrapporten van 25 (zeer) grote ondernemingen uit de VS geanalyseerd. Vanwege de verschillen met betrekking tot de externe verslaggeving zijn financiële instellingen niet opgenomen in ons onderzoek.

Het doel van dit artikel is om een overzicht te geven van de overeenkomsten en verschillen in regelgeving op dit terrein tussen Nederland, het IASC en de VS. Voorts willen we een empirisch onderzoek verrichten naar de implementatie van deze deels verschillende regels door ondernemingen. In het bijzonder wordt daarbij de relatie met het kapitaalbeschermingsrecht in Nederland onderzocht en de presentatie van de cumulatieve omrekeningsverschillen binnen het eigen vermogen (bij toepassing van de closing rate-methode) en de verwerking van deze verschillen in de jaarrekening bij verkoop van een buitenlandse deelneming. Aanleiding voor het onderzoek is de empirische constatering van Pronk en Van der Tas (1999) dat 70\% van de AEX- en Midkap-fondsen (exclusief financiële instellingen) voor het boek- jaar 1998 respectievelijk 1997/1998 de omrekeningsverschillen uit hoofde van toepassing van de closing rate-methode onder het hoofd 'overige reserves' verantwoorden. In de visie van de RJ vallen deze omrekeningsverschillen onder de klem van het kapitaalbeschermingsrecht en dienen niet op een vrije reserve te worden geboekt.

In paragraaf 2 wordt ingegaan op de wet- en regelgeving met betrekking tot de omrekening van deelnemingen luidende in vreemde valuta, voorzover relevant voor de scope van het empirisch onderzoek. Deze paragraaf wordt afgesloten met een tabel waarin de verschillen en overeenkomsten tussen de regelgeving op dit terrein worden samengevat. In paragraaf 3 wordt de weerslag van het empirisch onderzoek beschreven. Paragraaf 4 geeft de samenvatting van het artikel en enkele aanbevelingen.

\section{De wet- en regelgeving ten aanzien van de omrekening van deelnemingen luidende in vreemde valuta in Nederland, volgens het IASC en in de VS}

Bij de behandeling van de wet- en regelgeving gaan wij uit van de Nederlandse situatie. Daarna wordt telkens kort ingegaan op wat van toepassing is volgens de regels van het IASC alsmede wat van toepassing is in de VS (volgens de FASB).

De wetgeving in Nederland ten aanzien van vreemde valuta is beperkt. In Nederland is wat betreft de omrekening van vreemde valuta in art.

Prof. Dr. H.P.A.J. Langendijk is werkzaam als hoogleraar Externe Verslaggeving aan de Universiteit van Amsterdam en Universiteit Nyenrode.

$\mathrm{S}$. Bissesur was ten tijde van het schrijven van het artikel werkzaam als student-assistent aan de Universiteit van Amsterdam, faculteit der Economische Wetenschappen en Econometrie. 
2:385 lid 5 BW bepaald dat de grondslagen voor de omrekening van de in vreemde valuta luidende bedragen worden uiteengezet en dat wordt vermeld op welke wijze koersverschillen zijn verwerkt.

De RJ geeft in RJ 120.902 een definitie van buitenlandse bedrijfsuitoefening en wel de volgende: 'Bedrijfsuitoefening in het buitenland is een bedrijfsuitoefening die plaatsvindt door middel van deelnemingen, groepsmaatschappijen of filialen die hun jaarrekening of de daarvoor in de plaats tredende financiële verantwoordingen in een andere valuta dan de rapporteringvaluta van de rapporterende rechtspersoon opstellen'.

\section{Classificatie van de buitenlandse bedrijfsuitoefe- ning}

\section{$B W$ Titel 9 en Richtlijnen RJ}

De methode voor de omrekening van activa, passiva, baten en lasten met betrekking tot een activiteit luidende in vreemde valuta hangt af van de wijze waarop deze activiteit wordt gefinancierd, en van de relatie tussen de activiteiten van de rapporterende maatschappij met die van het buitenlandse bedrijf. In dit kader wordt elke buitenlandse bedrijfsuitoefening geclassificeerd als een 'buitenlandse eenheid' dan wel als een 'rechtstreekse buitenlandse activiteit' (RJ 120.913).

Overigens meldt Graafsma (1997, p. 692) dat het in de Nederlandse verslaggevingpraktijk voorkomt dat bij de omrekening van buitenlandse deelnemingen geen onderscheid wordt gemaakt tussen zelfstandige bedrijfsuitoefening in buitenlandse eenheden en rechtstreekse buitenlandse activiteiten. Op grond van het karakter van de belangrijkste buitenlandse activiteiten worden alle activiteiten hetzij als een buitenlandse eenheid hetzij als een rechtstreekse buitenlandse activiteit beschouwd.

Bij buitenlandse eenheden vindt de verkoop, het aangaan van verplichtingen en financiering uit hoofde van bedrijfsuitoefening met name plaats in lokale valuta. Hierbij wordt ervan uitgegaan dat de rapporterende rechtspersoon uitsluitend koersrisico loopt over haar netto-investering in de buitenlandse eenheid, ongeacht de activa en passiva van de buitenlandse activiteit. Activa en passiva van buitenlandse eenheden dienen te worden omgerekend tegen de koers per balansdatum (RJ 120.919). Omrekeningsverschillen dienen rechtstreeks in het eigen vermogen te worden verwerkt. Volgens de RJ moeten deze omrekeningsverschillen niet in de winst- en verliesrekening worden verwerkt, omdat de wijziging in de koer- sen weinig of geen invloed heeft op de huidige of toekomstige operationele kasstromen van zowel de buitenlandse eenheid als de rapporterende rechtspersoon (RJ 120.919). Het in het eigen vermogen opgenomen omrekeningsverschil bestaat uit drie componenten:

- het omrekeningsverschil op het begin eigen vermogen;

- het verschil tussen het in de winst- en verliesrekening opgenomen nettoresultaat (op basis van transactiekoersen of gemiddelde koersen) en de omrekening van het nettoresultaat tegen koers op balansdatum in de balans;

- het verschil tussen de omrekening van rechtstreekse vermogensmutaties tegen de koers op het moment waarop zij plaatsvinden en de omrekening daarvan tegen de koers op balansdatum.

Deze omrekeningsmethodiek wordt de closing rate-methode genoemd.

Indien sprake is van een aandeel van derden, wordt het daarop betrekking hebbende omrekeningsverschil daaraan toegerekend (Böhmer e.a., 2000 , p. 418-419). Posten van de winst- en verliesrekening dienen te worden omgerekend tegen de koersen op het moment van de transacties (RJ 120.919). Als benadering daarvan kunnen gewoonlijk de gemiddelde koersen voor de periode worden gehanteerd, mits deze niet tot grote verschillen leiden ten opzichte van de verwerking tegen de koers op het moment van aangaan van de transactie.

Bij rechtstreekse buitenlandse activiteiten vormen de activiteiten een onafscheidelijk deel van de moedermaatschappij. De buitenlandse activiteit wordt hierbij gezien als een verlengstuk van de activiteiten van de moeder. In RJ 120.914 wordt als voorbeeld gegeven een verkoopmaatschappij in het buitenland die uitsluitend goederen verkoopt van de moedermaatschappij. De rapporterende maatschappij wordt dan geacht koersrisico te lopen over de afzonderlijke activa en passiva. De activa, passiva, baten en lasten van rechtstreekse buitenlandse activiteiten dienen te worden omgerekend alsof de posten van de rapporterende rechtspersoon zelf zijn.

Dit betekent voor de balans dat indien waardering plaatsvindt tegen actuele waarde, de activa en passiva worden omgerekend tegen de koers op balansdatum, en de omrekeningsverschillen inzake de niet-monetaire tegen actuele waarde gewaardeerde posten worden opgenomen in een herwaarderingsreserve. Bij waardering tegen historische kosten worden de niet-monetaire posten omgerekend tegen de historische koers. De omre- 
keningsverschillen op monetaire posten worden in beide gevallen opgenomen in de winst- en verliesrekening. Deze omrekeningsmethodiek wordt de temporal-methode genoemd.

Voor de omrekening van de winst- en verliesrekening van de rechtstreekse buitenlandse activiteiten betekent dit dat de posten die samenhangen met de in de balans tegen historische koersen (koersen op balansdatum) omgerekende posten, eveneens tegen historische koersen (koersen op balansdatum) dienen te worden omgerekend. De overige posten van de winst- en verliesrekening dienen te worden omgerekend tegen koersen van het moment waarop zij in de administratie van de rechtstreekse buitenlandse activiteit zijn verwerkt (of tegen gemiddelde koersen).

\section{IASC}

De Nederlandse Richtlijnen zijn op dit terrein in overeenstemming met de regels van het IASC (zie IAS 21) (Böhmer e.a., 2000, p. 418).

\section{FASB}

Omrekening van deelnemingen luidende in vreemde valuta wordt volgens FAS 52 bepaald door het begrip functionele valuta. De functionele valuta is de munt die domineert in de economische omgeving waarin de desbetreffende buitenlandse eenheid werkzaam is. Activa, passiva en resultaten van een buitenlandse eenheid moeten worden gemeten in de functionele valuta. Voor een buitenlandse eenheid met een relatief zelfstandig karakter zal de functionele valuta in het algemeen de valuta van het land van vestiging zijn. Dergelijke buitenlandse eenheden worden omgerekend tegen de closing rate-methode.

Voor een buitenlandse eenheid waarvan de activiteiten nauw verbonden zijn met de activiteiten van de moedermaatschappij zal de functionele valuta doorgaans de valuta van de moedermaatschappij zijn. Dergelijke buitenlandse eenheden worden omgerekend tegen de temporal-methode. Ofschoon FAS 52 met het begrip 'functionele valuta' werkt en de begrippen 'rechtstreekse buitenlandse activiteiten' en 'activiteiten in buitenlandse eenheden' niet kent, is de omrekening van buitenlandse deelnemingen in hoofdlijnen hetzelfde als volgens de Richtlijnen van de RJ en IAS 21.

Presentatie van de rechtstreeks in het eigen vermogen verwerkte omrekeningsverschillen in de enkelvoudige jaarrekening

\section{BW Titel 9 en Richtlijnen RJ}

Binnen de enkelvoudige jaarrekening is met name de balans van betekenis, omdat daarin de relaties tot aandeelhouders, deelnemingen, schuldenaars en schuldeisers van de desbetreffende rechtspersoon tot uitdrukking komen. In het bijzonder komt het kapitaalbeschermingsrecht in de enkelvoudige balans tot uitdrukking.

De post 'Deelnemingen' moet - indien luidende in vreemde valuta - worden omgerekend naar de rapporteringvaluta. Uitgaande van de vermogensmutatiemethode en waardering op nettovermogenswaarde zullen de omrekeningsregels die in de geconsolideerde jaarrekening zijn toegepast met betrekking tot buitenlandse activiteiten ook moeten worden toegepast in de enkelvoudige jaarrekening van de moedermaatschappij. Dit houdt in dat bij toepassing van de closing rate-methode het omrekeningsverschil rechtstreeks in het eigen vermogen moet worden geboekt.

De omrekeningsverschillen die rechtstreeks in het eigen vermogen muteren, kunnen op verschillende rekeningen worden verantwoord:

- als een afzonderlijke niet-uitkeerbare reserve omrekeningsverschillen;

- als een bestanddeel van een herwaarderingsreserve;

- als een bestanddeel van een wettelijke reserve deelnemingen;

- als een bestanddeel van de vrije (overige) reserves.

Volgens de RJ zijn alleen de eerste drie rekeningen mogelijk (zie 120.933: stellige uitspraak). Dit wordt door de RJ nog nader onderstreept in alinea 120.931, waarin expliciet wordt gesteld dat deze omrekeningsverschillen als niet-uitkeerbaar moeten worden beschouwd. Het als uitkeerbaar beschouwen van deze omrekeningsverschillen zou immers in strijd zijn met de artikelen 2:389 lid 6 en/of 2:390 lid 1 BW. ${ }^{1}$

Graafsma (1997, p. 697-698) is van mening dat positieve omrekeningsverschillen niet op de vrije reserves kunnen worden geboekt. Graafsma geeft als reden dat het omrekeningsverschil op een deelneming betrekking heeft op een duurzaam ten dienste van de rechtspersoon staand op balansdatum aanwezig activum. Derhalve heeft dit omrekeningsverschil het karakter van een aan de bedrijfsuitoefening gebonden vermogenstoeneming of -vermindering. Dit brengt met zich mee dat de verwerking van het omrekeningsverschil niet kan leiden tot een toeneming van de vrij uitkeerbare reserves. Tegen de verwerking van negatieve omrekeningsverschillen bestaat volgens Graafsma (1997) in beginsel uit het oogpunt van kapitaalbescherming geen bezwaar. Het moge duidelijk zijn dat deze voorgestane scheiding in de 
verwerkingswijze van omrekeningsverschillen weinig consistent is. Alinea 120.933 van de RJ is dan veel duidelijker: omrekeningsverschillen dienen op een wettelijke reserve te worden geboekt (of zij nu negatief of positief zijn).

Bij verwerking van omrekeningsverschillen als onderdeel van een herwaarderingsreserve zijn de wettelijke bepalingen inzake de herwaarderingsreserve van toepassing. Van belang daarbij is dat bij uitputting van de herwaarderingsreserve verlies moet worden genomen (RJ 120.933).

Indien de niet-uitkeerbare reserve omrekeningsverschillen als gevolg van omrekeningsverliezen een debetsaldo vertoont, houdt dit niet in dat dit saldo ten laste van de winst- en verliesrekening moet worden aangevuld. Wel is de consequentie dat vrije reserves tot het bedrag van genoemd debetsaldo niet uitkeerbaar zijn (RJ 120.934). Ook kan het debetsaldo in mindering worden gebracht op de vrije reserves. Zodra weer sprake is van een creditsaldo dient de reserve omrekeningsverschillen weer te herleven.

Hetzelfde omrekeningsverschil kan dus worden gepresenteerd onder de herwaarderingsreserve of onder de post niet-uitkeerbare omrekeningsverschillen. In het eerste geval moet bij uitputting verlies worden getoond, in het tweede geval voorziet de RJ in een mutatie binnen het eigen vermogen op de vrije reserves. Het moge duidelijk zijn dat het presenteren van omrekeningsverschillen op een herwaarderingsreserve weinig aantrekkelijk is voor opstellers. De vrijheidsgraden om het getoonde resultaat te beïnvloeden zijn groter bij het boeken van de desbetreffende omrekeningsverschillen op de post niet-uitkeerbare omrekeningsverschillen. Het resultaat kan dan gemakkelijker worden geëgaliseerd.

Beckman e.a. (1999, 4.1.4-92) stellen dat de RJ over het hoofd ziet dat een koersverschillenreserve een herwaarderingsreserve is. Zodra deze reserve nihil wordt, is deze reserve uitgeput. Daaruit volgt dat een verder negatief verschil ten laste van het resultaat zou moeten komen. Er zijn daarom twee mogelijkheden:

- negatieve omrekeningsverschillen komen ten laste van het resultaat, ongeacht of de eerdere positieve omrekeningsverschillen eerst in een herwaarderingsreserve zijn opgenomen dan wel in een koersverschillenreserve;

- negatieve koersverschillen binnen de reserves zijn aanvaardbaar en dan doet het er niet toe of het om een herwaarderingsreserve dan wel een koersverschillenreserve gaat, daargelaten reeds dat een koersverschillenreserve ook een herwaarderingsreserve is.

Het moge duidelijk zijn dat de zienswijze van
Beckman e.a. (1999) consistenter lijkt dan de Richtlijnen van de RJ op dit punt, waarbij wij de eerste door Beckman e.a (1999) genoemde optie voorstaan.

\section{IASC}

In IAS 21 wordt niet expliciet aangegeven op welke rekening binnen het eigen vermogen de omrekeningsverschillen uit hoofde van omrekening van buitenlandse deelnemingen volgens de closing rate-methode moeten worden weergegeven. Ook op het wettelijke reserve-aspect van deze omrekeningsverschillen wordt in IAS 21 niet ingegaan.

\section{FASB}

Verwerking van de omrekeningsverschillen uit hoofde van omrekening van buitenlandse deelnemingen moet - in geval van toepassing van de closing rate-methode - via 'Other Comprehensive Income'. Dit Other Comprehensive Income is een onderdeel van het eigen vermogen van een onderneming. Op het aspect van wettelijke reserve wordt in de regelgeving in de VS niet ingegaan.

De verwerking van het (cumulatieve) bedrag van de rechtstreeks in het eigen vermogen verwerkte omrekeningsverschillen bij verkoop van een buitenlandse eenheid

\section{$B W$ Titel 9 en Richtlijnen RJ}

De RJ beveelt aan om bij verkoop van een buitenlandse eenheid (omgerekend tegen de closing rate-methode) het cumulatieve bedrag van de rechtstreeks in het eigen vermogen verwerkte omrekeningsverschillen met betrekking tot die buitenlandse eenheid in de winst- en verliesrekening te verwerken als onderdeel van het resultaat op de verkoop van de buitenlandse eenheid. Het in de winst- en verliesrekening verwerkte cumulatieve bedrag van de omrekeningsverschillen wordt dan afzonderlijk toegelicht. Het is als alternatief toegestaan deze verwerking van de cumulatieve omrekeningsverschillen in de winst- en verliesrekening achterwege te laten. De RJ geeft niet aan op welke rekening in het eigen vermogen deze cumulatieve omrekeningsverschillen moeten worden overgeboekt. Met Pronk en Van der Tas (1999, p. 52) nemen wij aan dat deze omrekeningsverschillen mogen worden overgeboekt naar de vrije reserves. De reden om een wettelijke reserve te vormen is namelijk door de verkoop vervallen.

Overigens leidt het in de winst- en verliesrekening verwerken van het cumulatieve omrekeningsverschil bij verkoop van een buitenlandse deelneming in de desbetreffende periode tot een vertekening van de resultaten door omrekeningsverschillen die niet in de desbetreffende periode 
zijn ontstaan. ${ }^{2}$ Als deze redenering zou worden doorgetrokken, zouden de omrekeningsverschillen in de winst- en verliesrekening moeten worden verwerkt in de periode dat zij ontstaan. Dit zou passen bij een balans op basis van fair value met de (on)gerealiseerde resultaten in de winst- en verliesrekening.

IASC

IAS 21 par. 37 bepaalt dat de cumulatieve omrekeningsverschillen op buitenlandse eenheden die rechtstreeks naar het eigen vermogen zijn geboekt, bij verkoop of liquidatie van de desbetreffende deelneming alsnog in de winst- en verliesrekening moeten worden verantwoord en dus niet rechtstreeks naar de vrije reserves mogen worden geboekt.

Volgens plannen van de Europese Unie (EU) moeten ter beurze genoteerde ondernemingen binnen de EU hun jaarverslaggeving gaan baseren op de regels van het IASC (EU, 1999).

Naar verwachting zullen de regels van het IASC op zijn laatst met ingang van boekjaar 2005 door Nederlandse ter beurze genoteerde ondernemingen moeten zijn ingevoerd. Als gevolg daarvan is het mogelijk dat een aantal van deze ondernemingen buitenlandse dochtermaatschappijen met een (zeer) groot negatief cumulatief omrekeningsverschil zullen verkopen, voordat zij hun regels hebben aangepast. Op deze wijze kunnen deze ondernemingen ontlopen dat hun winst- en verliesrekeningen worden belast met de negatieve cumulatieve omrekeningsverschillen, indien zij hun buitenlandse dochtermaatschappijen na aanpassing verkopen. Dit kan worden beschouwd als een economische consequentie van de invoering van verslaggevingregels (zie Scott, 1997, hoofdstuk 8 , voor een algemene uitweiding over economische consequenties van verslaggevingregels).

\section{$F A S B$}

De regels van de FASB (FAS 52) zijn in overeenstemming met de regels van het IASC.

De regels van het IASC en het FASB zijn op dit terrein dus strikter dan de regels van de RJ.

Toepassing van het (uitgebreide) net investmentconcept in het geval van omrekening van deelnemingen luidende in vreemde valuta die tegen de closing rate worden omgerekend

\section{$B W$ Titel 9 en Richtlijnen RJ}

Indien vorderingen en schulden moeten worden beschouwd als een uitbreiding of inkrimping van de netto-investering van de moedermaatschappij in een buitenlandse eenheid, moeten de ongereali- seerde koersverschillen met betrekking tot de omrekening van deze vorderingen en schulden worden verwerkt in het eigen vermogen ( $R J$ 120.909). Dezelfde behandeling geldt indien een lening in een vreemde valuta is aangegaan om de netto-investering in een buitenlandse eenheid te financieren of af te dekken, voorzover deze effectief zijn als dekking van de koersverschillen voortvloeiende uit de netto-investering in de desbetreffende buitenlandse eenheid (RJ 120.910).

\section{IASC}

In IAS 21 paragrafen 17, 18 en 19 zijn de regels vervat met betrekking tot de toepassing van het net investment-concept. Op hoofdlijnen zijn de regels van het IASC in overeenstemming met de regels van de $\mathrm{RJ}$ ten aanzien van de toepassing van het net investment-concept. Wel geeft het IASC expliciet aan welke vorderingen en schulden een uitbreiding of inkrimping zijn van de netto-investering van de moedermaatschappij. Volgens IAS 21 paragraaf 18 behoren handelsdebiteuren en handelscrediteuren niet tot de intragroepsvorderingen en -schulden die een uitbreiding of inkrimping zijn van de netto-investering van de moedermaatschappij. De RJ laat zich hierover niet expliciet uit.

\section{FASB}

In FAS 52 paragrafen 20 en 21 worden regels gegeven met betrekking tot de toepassing van het net investment-concept. Indien sprake is van transacties in vreemde valuta met als oogmerk een economische hedge van een netto-investering in een buitenlandse eenheid, moeten de resultaten van deze hedge als een rechtstreekse vermogensmutatie worden beschouwd. Hetzelfde geldt voor intercompany-transacties in vreemde valuta op lange termijn.

Op hoofdlijnen komen de regels van de RJ, het IASC (IAS 21) en FASB (FAS 52) met betrekking tot het net investment-concept overeen.

\section{Toelichting}

\section{$B W$ Titel 9 en Richtlijnen RJ}

De bedragen van de omrekeningsverschillen bij bedrijfsuitoefening in het buitenland die rechtstreeks in het eigen vermogen, respectievelijk in de winst- en verliesrekening zijn verwerkt, dienen in de toelichting te worden vermeld. Voor de in het eigen vermogen verwerkte koersverschillen dient in de toelichting een mutatieoverzicht over de rapporteringperiode te worden opgenomen (alinea 120.937). 
IASC

De eisen voor de toelichting van de RJ zijn gelijk aan die van het IASC.

\section{$F A S B$}

Het FASB eist volgens FAS 52 daarenboven een analyse van veranderingen in de cumulative translation adjustment als component van Other Comprehensive Income (FAS 52 par. 31 en 32). Voor het overige zijn de eisen voor de toelichting materieel gelijk aan IAS 21 en RJ 120. Hierbij moet wel worden aangetekend dat het mutatieoverzicht Eigen Vermogen in Nederland wettelijk verplicht is bij de vennootschappelijke jaarrekening. Volgens de regels van de FASB gaat het om een mutatieoverzicht Eigen Vermogen of comprehensive income statement als onderdeel van de geconsolideerde 'statements'.

Tabel 1 geeft een samenvatting van de belangrijkste overeenkomsten en verschillen ten aanzien van de problematiek zoals behandeld in dit artikel.

\section{Empirisch onderzoek naar de omrekening van deelnemingen luidende in vreemde valuta naar de rapporteringvaluta}

In deze paragraaf wordt verslag gedaan van de bevindingen van een descriptief onderzoek naar de omrekening van deelnemingen luidende in vreemde valuta naar de rapporteringvaluta voor 25 AEX-ondernemingen, 25 ondernemingen die volgens de regels van het IASC rapporteren en 25 ondernemingen uit de VS. Financiële instellingen zijn van onze recherche uitgesloten. Wij hebben ons onderzoek gericht op de jaarrapporten 1999 (inclusief gebroken boekjaren 1998/1999 en 1999/2000). In Bijlage 1 is een lijst opgenomen van de in het onderzoek betrokken ondernemingen/jaarrapporten ${ }^{3}$.

Het empirisch onderzoek heeft zich beperkt tot de volgende elementen:

- methode van omrekening van deelnemingen luidende in vreemde valuta (closing rateversus temporal-methode);

- gehanteerde koers voor het omrekenen van de winst- en verliesrekening van deelnemingen luidende in vreemde valuta (gemiddelde koers, koers datum transactie, eindkoers);

- verwerking van het omrekeningsverschil met betrekking tot de omrekening van de balans (in de winst- en verliesrekening of rechtstreeks in het eigen vermogen);

- presentatie van het omrekeningsverschil in geval van toepassing van closing rate (mutatieoverzicht Eigen Vermogen of als (Other) Comprehensive Income);

- naam rekening voor het omrekeningsverschil in geval van toepassing van closing ratemethode (cumulatieve translatieverschillen, wettelijke reserves of vrije reserves);

- verantwoording van de (cumulatieve) omrekeningsverschillen bij de verkoop van deelnemingen luidende in vreemde valuta, die in het verleden zijn omgerekend tegen de closing rate-methode ((cumulatief) omrekeningsverschil in de winst- en verliesrekening of in het eigen vermogen);

- toepassing van het (uitgebreide) net investment-concept in het geval van omrekening van deelnemingen luidende in vreemde valuta die tegen de closing rate worden omgerekend.

Toepassing van balansomrekening volgens de closing rate-methode respectievelijk de temporalmethode

In hun jaarrapport geven 72 (96\%) ondernemingen expliciet weer dat zij de closing rate-methode hanteren. Drie ondernemingen (4\%) (Hewlett Packard, Libertel en Intel) passen de temporalmethode toe. In grote meerderheid wordt de closing rate-methode gehanteerd. Dit is te verklaren vanwege het feit dat de getoonde resultaten ceteris paribus - minder volatiel zijn dan bij toepassing van de temporal-methode. Voorts is de closing rate-methode administratief eenvoudig en houdt deze methode de balansverhoudingen (zoals zij waren voor omrekening) intact.

Omrekeningskoers met betrekking tot de omrekening van de winst- en verliesrekening van deelnemingen luidende in vreemde valuta

Voorzover ondernemingen een toelichting geven, is het de gemiddelde koers die gebruikt wordt. Eenentwintig AEX-ondernemingen hanteren de gemiddelde koers, één (TPG) hanteert de contante koers of een gemiddelde administratieve koers, één (Heineken) hanteert de dagkoers en twee ondernemingen geven geen toelichting. Twintig ondernemingen die volgens IASC-regels rapporteren hanteren de gemiddelde koers, vijf geven geen toelichting.

Tien ondernemingen uit de VS hanteren de gemiddelde koers, vijftien ondernemingen geven geen toelichting.

Over het algemeen wordt de gemiddelde koers gebruikt voor de omrekening van winst- en verliesrekeningen. Deze methodiek is een weerspiegeling van het feit dat een winst- en verliesrekening een stroomgrootheid is. 
Tabel 1: Overeenkomsten en verschillen in de regelgeving met betrekking tot de omrekening van deelnemingen luidende in vreemde valuta naar de rapporteringvaluta tussen Nederland, het IASC en de VS

\begin{tabular}{|c|c|c|c|c|}
\hline & $\begin{array}{l}\text { Nederlandse wet- } \\
\text { en regelgeving }\end{array}$ & $I A S C$ (IAS 21) & $\begin{array}{l}\text { Verenigde Staten } \\
\text { (FASB: FAS 52) }\end{array}$ & $\begin{array}{l}\text { Overeenkomsten/ } \\
\text { verschillen }\end{array}$ \\
\hline $\begin{array}{l}\text { Classificatie van de } \\
\text { buitenlandse bedrijfs- } \\
\text { uitoefening }\end{array}$ & $\begin{array}{l}\text { Activiteiten in buiten- } \\
\text { landse eenheden } \\
\text { (closing rate-methode) } \\
\text { versus rechtstreekse } \\
\text { buitenlandse } \\
\text { activiteiten (temporal- } \\
\text { methode) }\end{array}$ & $\begin{array}{l}\text { Idem als Nederlandse } \\
\text { regelgeving }\end{array}$ & $\begin{array}{l}\text { Functionele valuta } \\
\text { staat centraal }\end{array}$ & $\begin{array}{l}\text { Onderscheidend } \\
\text { criterium verschillend } \\
\text { tussen enerzijds } \\
\text { Nederlandse wet en } \\
\text { regelgeving en het IASC } \\
\text { en anderzijds de VS; } \\
\text { omrekening in hoofd- } \\
\text { lijnen veelal hetzelfde }\end{array}$ \\
\hline $\begin{array}{l}\text { Presentatie van de } \\
\text { rechtstreeks in het } \\
\text { eigen vermogen } \\
\text { verwerkte } \\
\text { omrekenings- } \\
\text { verschillen de enkel- } \\
\text { voudige jaarrekening }\end{array}$ & $\begin{array}{l}\text { Omrekeningsverschil- } \\
\text { len moeten worden } \\
\text { verantwoord op een } \\
\text { wettelijke reserve } \\
\text { binnen het eigen } \\
\text { vermogen }\end{array}$ & $\begin{array}{l}\text { IAS } 21 \text { geeft niet } \\
\text { expliciet aan op welke } \\
\text { rekening binnen het } \\
\text { eigen vermogen de } \\
\text { omrekeningsverschil- } \\
\text { len moeten worden } \\
\text { weergegeven. } \\
\text { Op het aspect } \\
\text { wettelijke reserve } \\
\text { wordt niet ingegaan }\end{array}$ & $\begin{array}{l}\text { Omrekeningsverschil- } \\
\text { len moeten worden } \\
\text { gepresenteerd als } \\
\text { Other Comprehensive } \\
\text { Income onder het } \\
\text { (geconsolideerd) } \\
\text { eigen vermogen. } \\
\text { Op het aspect } \\
\text { wettelijke reserve } \\
\text { wordt niet ingegaan }\end{array}$ & $\begin{array}{l}\text { Volgens de Nederlandse } \\
\text { regelgeving moeten de } \\
\text { omrekeningsverschillen } \\
\text { op een wettelijke } \\
\text { reserve worden verant- } \\
\text { woord. FASB en IASC } \\
\text { kennen geen wettelijke } \\
\text { reserves }\end{array}$ \\
\hline $\begin{array}{l}\text { Verwerken } \\
\text { (cumulatief) om- } \\
\text { rekeningsverschil bij } \\
\text { verkoop buitenlandse } \\
\text { eenheid }\end{array}$ & $\begin{array}{l}\text { Aanbevolen wordt } \\
\text { verwerking van het } \\
\text { (cumulatief) } \\
\text { omrekeningsverschil } \\
\text { in het resultaat, als } \\
\text { alternatief is } \\
\text { verwerking in het eigen } \\
\text { vermogen toegestaan }\end{array}$ & $\begin{array}{l}\text { Het (cumulatief) } \\
\text { omrekeningsverschil } \\
\text { moet worden verwerkt } \\
\text { via het resultaat }\end{array}$ & Idem als IASC & $\begin{array}{l}\text { IASC en FASB zijn } \\
\text { strikter. Zij staan geen } \\
\text { verwerking van het } \\
\text { (cumulatief) } \\
\text { omrekeningsverschil } \\
\text { toe via het eigen } \\
\text { vermogen }\end{array}$ \\
\hline $\begin{array}{l}\text { Toepassing } \\
\text { (uitgebreide) net } \\
\text { investment-concept }\end{array}$ & $\begin{array}{l}\text { Moet worden } \\
\text { toegepast indien er } \\
\text { sprake is van een } \\
\text { uitbreiding of } \\
\text { inkrimping van de } \\
\text { netto-investering van } \\
\text { de moedermaatschap- } \\
\text { pij in een buitenlandse } \\
\text { eenheid }\end{array}$ & $\begin{array}{l}\text { Idem als Nederlandse } \\
\text { regelgeving }\end{array}$ & $\begin{array}{l}\text { Idem als Nederlandse } \\
\text { regelgeving }\end{array}$ & Geen verschillen \\
\hline Toelichting & $\begin{array}{l}\text { Omrekenings- } \\
\text { verschillen toelichten. } \\
\text { Voor in het eigen } \\
\text { vermogen verwerkte } \\
\text { omrekeningsverschillen } \\
\text { moet een mutatie- } \\
\text { overzicht worden } \\
\text { opgenomen }\end{array}$ & $\begin{array}{l}\text { Idem als Nederlandse } \\
\text { regelgeving }\end{array}$ & $\begin{array}{l}\text { Behoudens de } \\
\text { toelichting zoals in } \\
\text { Nederland en volgens } \\
\text { het IASC moet een } \\
\text { analyse worden } \\
\text { gegeven van de } \\
\text { veranderingen in de } \\
\text { rekening omrekenings- } \\
\text { verschillen als } \\
\text { component van Other } \\
\text { Comprehensive Income }\end{array}$ & $\begin{array}{l}\text { Eisen toelichting zijn } \\
\text { voor Nederland en het } \\
\text { IASC gelijk. In de VS } \\
\text { wordt voorts een } \\
\text { analyse gevraagd van } \\
\text { de rekening } \\
\text { Cumulatieve } \\
\text { omrekeningsverschillen }\end{array}$ \\
\hline
\end{tabular}


Presentatie (inclusief de rekeningomschrijving) van de omrekeningsverschillen met betrekking tot de omrekening van deelnemingen luidende in vreemde valuta

Over het algemeen worden de omrekeningsverschillen door AEX-ondernemingen getoond in het mutatieoverzicht Eigen Vermogen. Twee AEXondernemingen tonen hun omrekeningsverschillen onder het hoofd Comprehensive Income (Koninklijke Olie en KPN). Beide ondernemingen hebben tevens een notering in de VS.

Alle IASC-ondernemingen tonen hun omrekeningsverschillen in het mutatieoverzicht Eigen Vermogen.

Twintig ondernemingen uit de VS rapporteren omrekeningsverschillen in het mutatieoverzicht Eigen Vermogen. Vijf ondernemingen uit de VS rapporteren hun omrekeningsverschillen in een afzonderlijke Comprehensive Income Statement. Zowel presentatie van de omrekeningsverschillen in het mutatieoverzicht Eigen Vermogen als in een afzonderlijke Comprehensive Income Statement is in de VS toegestaan. Een geleidelijke overgang van Amerikaanse ondernemingen naar presentatie van de omrekeningsverschillen in een afzonderlijke Comprehensive Income Statement is te verwachten, omdat laatstgenoemd 'total' performanceoverzicht voor professionele gebruikers gemakkelijker toegankelijk is dan het mutatieoverzicht Eigen Vermogen. Ter illustratie is het Consolidated Statement of Comprehensive Income van Chevron opgenomen.
Dit is een afzonderlijk overzicht dat door Chevron in hun jaarrapport direct is geplaatst onder de geconsolideerde winst- en verliesrekening. Het bedrag aan Other Comprehensive Income voor 1999 (-/-25) komt overeen met de mutatie in Accumulated Other Comprehensive Income als onderdeel van Total Stockholders' Equity. Op deze wijze kunnen gebruikers snel kennis nemen van de 'totale' performance van Chevron.

Door negen AEX-ondernemingen worden omrekeningsverschillen met betrekking tot deelnemingen luidende in vreemde valuta rechtstreeks in de overige reserves gemuteerd. Dit is in tegenspraak met alinea 120.931; stellige uitspraak van de $\mathrm{RJ}^{4}$. Op deze wijze wordt door deze ondernemingen de suggestie gewekt alsof deze omrekeningsverschillen vrij uitkeerbaar zijn (zie de in dit artikel opgenomen illustratie ontleend aan het jaarrapport van Getronics). In de visie van de RJ vallen deze omrekeningsverschillen onder de klem van het kapitaalbeschermingsrecht. Pronk en Van der Tas (1999, p. 57) signaleerden in een onderzoek onder AEX- en Midkap-fondsen (exclusief financiële instellingen) voor het boekjaar 1998 respectievelijk 1997/1998 dat 31 van de 44 ondernemingen (70\%) omrekeningsverschillen uit hoofde van toepassing van de closing rate-methode onder het hoofd Overige reserves verantwoordden. Uit ons onderzoek - onder een beperktere populatie blijkt dat deze (onjuiste) presentatiewijze van omrekeningsverschillen is afgenomen.

In IAS 21 wordt gesproken over exchange differences of cumulative exchange differences. Deze bewoordingen hebben wij niet aangetroffen voor

Overzicht Consolidated Statement of Comprehensive Income van Chevron (Annual report Chevron, 1999, p. 33):

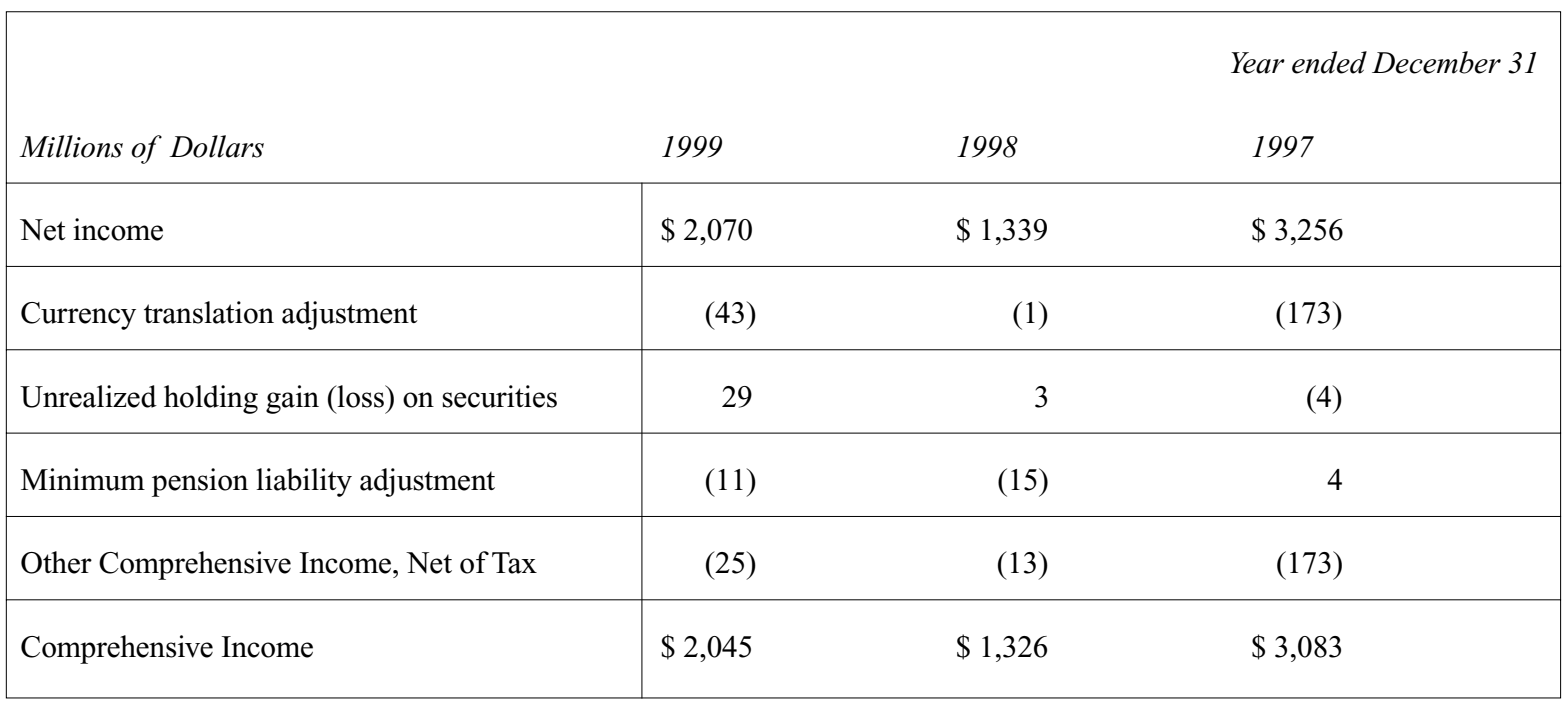


Tabel 2: Rekeningomschrijving omrekeningsverschillen binnen het eigen vermogen

\begin{tabular}{|c|c|c|c|}
\hline Rekeningomschrijving & $\begin{array}{l}A E X- \\
\text { ondernemingen * }\end{array}$ & $\begin{array}{l}\text { Ondernemingen die } \\
\text { volgens de regels van } \\
\text { het IASC rapporteren * }\end{array}$ & $\begin{array}{l}\text { Ondernemingen die } \\
\text { volgens de regels in } \\
\text { de VS rapporteren * }\end{array}$ \\
\hline Wettelijke reserve deelnemingen & 1 & & \\
\hline Herwaarderingsreserve & 1 & & \\
\hline Reserve koersverschillen & 2 & & \\
\hline Reserve Omrekeningsverschillen & 3 & & \\
\hline Cumulatieve valuta omrekeningsverschillen & 4 & & \\
\hline Vreemde valuta koersverschillen & 1 & & \\
\hline Overige reserves & 9 & 2 & \\
\hline Foreign currency translation adjustment & & 3 & 8 \\
\hline Cumulative translation adjustment & & 8 & 8 \\
\hline Translation adjustment net of tax & & & 1 \\
\hline Translation adjustment & & 6 & 2 \\
\hline Revenue reserve & & 2 & \\
\hline Equity attributable to shareholders & & 1 & \\
\hline Translation reserve & & 1 & \\
\hline
\end{tabular}

* Het aantal rekeningen sluit niet op 25, omdat sommige ondernemingen verschillende rekeningen onder het eigen vermogen gebruiken om omrekeningsverschillen op buitenlandse deelnemingen tot uitdrukking te brengen, sommige ondernemingen geen omrekeningsverschillen hadden of de temporal-methode toepassen.

de omrekeningsverschillen uit hoofde van toepassing van de closing rate-methode. Veeleer troffen wij bewoordingen aan die duiden op een vrije reserve of een (cumulative) translation adjustment. IAS 21 geeft overigens niet aan dat deze omrekeningsverschillen op een specifieke rekening onder het eigen vermogen moeten worden verantwoord.

In FAS 52 wordt als omschrijving gebruikt de bewoordingen translation adjustment of cumulative translation adjustment voor het omrekeningsverschil uit hoofde van toepassing van de closing rate-methode. Deze bewoordingen worden over het algemeen ook gehanteerd door de onderzochte ondernemingen in de VS. FAS 52 geeft overigens niet aan dat deze omrekeningsverschillen op een specifieke rekening onder het eigen vermogen moeten worden verantwoord.
In Tabel 2 zijn de benamingen van de rekeningen met betrekking tot omrekeningsverschillen binnen het eigen vermogen opgenomen zoals door de auteurs aangetroffen in de onderzochte populatie.

Verwerking van de gecumuleerde omrekeningsverschillen (in geval van toepassing van de closing rate-methode) bij verkoop van deelnemingen luidende in vreemde valuta

In de jaarrapporten van de AEX-ondernemingen wordt driemaal melding gemaakt van de verkoop van een buitenlandse deelneming, waarbij het (cumulatieve) omrekeningsverschil in het resultaat wordt opgenomen. Dit betreft de ondernemingen ASML, Koninklijke Olie en Philips. De verwerking in het resultaat door de drie voornoemde ondernemingen kan het gevolg zijn van het feit 
Het mutatieoverzicht Eigen Vermogen uit de toelichting op de enkelvoudige jaarrekening van Getronics NV 1999, p. 61:

\begin{tabular}{|c|c|c|c|c|c|c|}
\hline Eigen vermogen & $\begin{array}{l}\text { Cumulatief } \\
\text { preferente } \\
\text { aandelen }\end{array}$ & $\begin{array}{l}\text { Gewone } \\
\text { aandelen }\end{array}$ & $\begin{array}{l}\text { Agio op } \\
\text { cumulatief } \\
\text { preferente } \\
\text { aandelen }\end{array}$ & $\begin{array}{l}\text { Agio op } \\
\text { gewone } \\
\text { aandelen }\end{array}$ & $\begin{array}{l}\text { Overige } \\
\text { reserves }\end{array}$ & Totaal \\
\hline Stand per 1 januari 1999 & - & 10 & - & 116 & 39 & 165 \\
\hline Dividendafrekening vorig boekjaar & - & - & - & - & - & 1 \\
\hline Aandelenemissies & 2 & 3 & 232 & 773 & - & 1.010 \\
\hline Koersverschillen & - & - & - & - & $-/-6$ & $-/-6$ \\
\hline Resultaat boekjaar & - & - & - & - & 118 & 118 \\
\hline $\begin{array}{l}\text { Reservering voor cumulatief } \\
\text { preferent dividend over het boekjaar }\end{array}$ & - & - & - & - & $-/-6$ & $-/-6$ \\
\hline Reservering voor contant dividend & - & - & - & - & $-/-11$ & $-/-11$ \\
\hline Stand per 31 december 1999 & 2 & 13 & 232 & 889 & 135 & 1.271 \\
\hline
\end{tabular}

dat deze drie ondernemingen tevens een notering hebben in de VS, en derhalve zoveel mogelijk hun jaarrapport opmaken volgens Amerikaanse verslaggevingregels die ook in Nederland zijn toegestaan $^{5}$. In Nederland is zowel verwerking in het eigen vermogen als verwerking in het resultaat volgens de regelgeving van de RJ toegestaan. De overige $22 \mathrm{AEX}$-ondernemingen verschaffen geen informatie omtrent de verkoop van een deelneming luidende in vreemde valuta. Een verkoop van een buitenlandse deelneming behoeft in het onderzochte boekjaar niet te hebben plaatsgevonden.

Drie ondernemingen die volgens de regels van het IASC rapporteren, melden dat zij de gecumuleerde omrekeningsverschillen bij verkoop van deelnemingen luidende in vreemde valuta verwerken in de winst- en verliesrekening (Alcan Alumimium, Nokia, en Roche). Dit is in overeenstemming met IAS 21. De overige 22 ondernemingen geven geen informatie omtrent de verkoop van deelnemingen luidende in vreemde valuta. Een verkoop hoeft niet plaatsgevonden te hebben en/of de onderneming in kwestie past de temporalmethode toe.

Zes Amerikaanse ondernemingen maken melding van de verwerking van de cumulatieve omrekeningsverschillen met betrekking tot de verkoop van een buitenlandse deelneming in de winst- en verliesrekening (Apple, General Electric, Hewlett
Packard, International Paper, John Deere en Philips Petroleum). Dit is in overeenstemming met FAS 52. De overige 19 ondernemingen verschaffen geen informatie omtrent de verkoop van een deelneming luidende in vreemde valuta. Een verkoop hoeft niet plaatsgevonden te hebben en/of de onderneming in kwestie past de temporal-methode toe.

\section{Samenvatting}

In dit artikel is verslag gedaan van een aantal elementen van de omrekening van deelnemingen luidende in vreemde valuta naar de rapporteringvaluta. Daartoe is een onderzoek verricht naar de vigerende regelgeving op dit terrein en is een beperkt empirisch onderzoek verricht naar de verslaggevingpraktijk. Hiertoe zijn de jaarrekeningen van $25 \mathrm{AEX}$-ondernemingen, 25 ondernemingen die volgens de regels van de FASB rapporteren alsmede 25 ondernemingen die volgens IASCregels rapporteren aan een onderzoek onderworpen.

De regelgeving is op hoofdlijnen hetzelfde, met dien verstande dat er wel enkele verschillen zijn te constateren. Zo kent FAS 52 het begrip functionele valuta en niet het onderscheid tussen rechtstreekse buitenlandse activiteiten en buitenlandse eenheden. Materieel komt het hanteren van het begrip functionele valuta wel op hetzelfde neer.

Wettelijke reserves zijn bij het IASC en FASB, in 
tegenstelling tot bij de RJ, geen issue. Dit heeft tot gevolg dat een discussie over wel of niet op een wettelijke reserve boeken van omrekeningsverschillen niet relevant is voor deze regelgevers. Wel is FAS 52 zeer uitgesproken over de plaats waar het omrekeningsverschil uit hoofde van toepassing van de closing rate-methode moet worden geboekt. Dit moet op de rekening Other Comprehensive Income zijn.

Een belangrijk verschil is er met betrekking tot de behandeling van de cumulatieve omrekeningsverschillen bij verkoop van buitenlandse deelnemingen. Volgens het IASC en de FASB moeten deze omrekeningsverschillen in het resultaat worden opgenomen. De RJ beveelt dit slechts aan. Als alternatief mogen deze verschillen volgens de RJ in het eigen vermogen worden verwerkt. Naar onze mening zou de RJ het IASC en de FASB op dit punt moeten volgen en alleen verwerking van het cumulatieve omrekeningsverschil via het resultaat moeten toestaan. Dit komt de internationale vergelijkbaarheid ten goede en is in overeenstemming met het all-inclusive concept of income. Overigens hebben wij geen informatie aangetroffen in de onderzochte jaarrekeningen van AEXondernemingen die duidt op het verwerken van de cumulatieve omrekeningsverschillen bij verkoop van een buitenlandse deelneming in het eigen vermogen.

Uit ons onderzoek komt duidelijk naar voren dat de closing rate-methode de standaard is voor de omrekening van balansen van buitenlandse deelnemingen en dat de gemiddelde koers veelal wordt gehanteerd voor de omrekening van de winst- en verliesrekening.

Voorts blijkt dat een aantal Nederlandse ondernemingen ten onrechte hun omrekeningsverschillen uit hoofde van de toepassing van de closing rate-methode muteren op de vrije reserves (overige reserves). Dit is in strijd met de regels van de $\mathrm{RJ}$ en het kapitaalbeschermingsrecht. Deze omrekeningsverschillen moeten op een wettelijke reserve worden geboekt. Verder valt op dat omrekeningsverschillen op een brede waaier aan verschillende rekeningen onder het eigen vermogen worden geboekt. Hierbij valt het op dat de RJ de niet-uitkeerbare reserve omrekeningsverschillen niet als een herwaarderingsreserve beschouwt. Dit heeft tot gevolg dat bij uitputting van deze reserve een verder negatief verschil niet ten laste van het resultaat komt (zoals bij een reguliere herwaarderingsreserve). Wij staan een gelijke behandeling voor van omrekeningsverschillen, of zij nu op een herwaarderingsreserve of op een niet-uitkeerbare reserve omrekeningsverschillen worden geboekt. Deze gelijke behandeling houdt in dat bij uitput- ting van de twee voornoemde reserves een verder negatief verschil ten laste van het resultaat komt. De RJ zou de regelgeving op dit terrein moeten aanpassen.

Een beperkt aantal ondernemingen hanteert het uitgebreide net investment-concept.

De RJ zou de omschrijving van het uitgebreide net investment-concept verder moeten aanscherpen. In overeenstemming met IAS 21 paragraaf 18 moet worden opgenomen dat de handelsdebiteuren en handelscrediteuren niet tot de intragroepsvorderingen en -schulden behoren die een uitbreiding of inkrimping zijn van de netto-investering van de moedermaatschappij.

\section{LITERAT U UR}

Beckman, H., A.J. Bindenga, W.N. Meijer, F. Krens en H. Smits (red.) (1999), Compendium voor de jaarrekening, Kluwer: Deventer, losbladig bijgewerkt tot afl. 57.

Böhmer, S., M.N. Hoogendoorn, F. de Kam en F. Krens (red.) (2000), Ernst \& Young Handboek Jaarrekening 2000, Ernst \& Young: Rotterdam.

Deloitte \& Touche en Vereniging VNO-NCW (2000), Internationale verslaggevingregels: Wat betekenen ze voor Nederlandse ondernemingen, Deloitte \& Touche en Vereniging VNO-NCW: Den Haag.

Ernst \& Young (2000), International Accounting Standards: Vergelijking met Nederlandse wet- en regelgeving, Ernst \& Young: Rotterdam.

Europese Unie (1999), EU Financial Reporting Strategy: the way forward, Europese Unie.

Financial Accounting Standards Board (1981), Statement of Financial Accounting Standards No. 52 Foreign Currency Translation, FASB: Stamford.

Financial Accounting Standards Board (1997), Statement of Financial Accounting Standards No. 130 Reporting Comprehensive Income, FASB: Norwalk.

Graafsma, S.L.J. (1997), 30 Vreemde valuta, in: Externe verslaggeving in theorie en praktijk, red. M.N. Hoogendoorn, J. Klaassen en F. Krens, DELWEL: Den Haag, pp. 670-703.

International Accounting Standards Committee (2000), International Accounting Standards 2000, International Accounting Standards Committee: Londen.

Pronk, M. en L.G. van der Tas (1999), Vreemde valuta in de jaarrekening, Het jaar 1998 verslagen, red. J. Dijksma, J.A.G.M. Koevoets en R.G.A. Vergoossen, Nivra geschriften 69, Kluwer: Deventer, pp. 45-64.

Raad voor de Jaarverslaggeving (1999), Richtlijnen voor de jaarverslaggeving Jaareditie 1999, Kluwer: Deventer. 
Bijlage 1: Lijst van in het onderzoek betrokken ondernemingen/jaarrapporten (25 AEX-ondernemingen, 25 ondernemingen die volgens de regels van het IASC rapporteren en 25 ondernemingen die volgens de regels in de Verenigde Staten rapporteren.

\begin{tabular}{|c|c|c|}
\hline $\begin{array}{l}\text { Ondernemingen met een } \\
\text { notering aan de } A E X \text {, die } \\
\text { volgens de Nederlandse } \\
\text { regels rapporteren }\end{array}$ & $\begin{array}{l}\text { Ondernemingen die volgens } \\
\text { de regels van het IASC } \\
\text { rapporteren }\end{array}$ & $\begin{array}{l}\text { Ondernemingen die volgens } \\
\text { de regels in de Verenigde Staten } \\
\text { rapporteren }\end{array}$ \\
\hline Ahold 1999 & ABB 1999 & Apple 1998/1999 \\
\hline Akzo Nobel 1999 & Alcan Aluminium 1999 & Bell Atlantic 1999 \\
\hline ASML 1999 & BHP 1998/1999 & Chevron 1999 \\
\hline Baan 1999 & Delhaize 1999 & Dow Chemical 1999 \\
\hline DSM 1999 & Fiat 1999 & General Electric 1999 \\
\hline Getronics 1999 & Fuijtsu 1998/1999 & General Motors 1999 \\
\hline Hagemeijer 1999 & Gucci 1999 & Hewlett Packard 1998/1999 \\
\hline Heineken 1999 & Henkel 1999 & Goodyear 1999 \\
\hline IHC Caland 1999 & Imperial Oil 1999 & IBM 1999 \\
\hline KLM 1999/2000 & Kajima 1998/1999 & Intel 1999 \\
\hline Koninklijke Olie 1999 & Kvaerner 1999 & International Paper 1999 \\
\hline KPN 1999 & Libertel 1999/2000 & John Deere 1998/1999 \\
\hline Laurus 1999 & Lufthansa 1999 & Johnson \& Johnson 1999 \\
\hline Nedloyd 1999 & LVMH 1999 & Lockheed Martin 1999 \\
\hline Numico 1999 & Nestlé 1999 & MacDonalds 1999 \\
\hline Nutreco 1999 & Nokia 1999 & Motorola 1999 \\
\hline Océ 1998/1999 & Novartis 1999 & Pfizer 1999 \\
\hline Philips 1999 & Pinault 1999 & Philips Petroleum 1999 \\
\hline TPG 1999 & Preussag 1998/1999 & Sara Lee 1998/1999 \\
\hline Unilever 1999 & Renault 1999 & SBC Communications 1999 \\
\hline UPC 1999 & Roche 1999 & Sears Roebuck 1999 \\
\hline Vedior 1999 & RWE 1999/2000 & United Airlines 1999 \\
\hline Vendex KBB 1999/2000 & Statoil 1999 & United Technologies 1999 \\
\hline VNU 1999 & UPM Kymmene 1999 & Texaco 1999 \\
\hline Wolters Kluwer 1999 & Viag 1999 & Xerox 1999 \\
\hline
\end{tabular}

Raad voor de Jaarverslaggeving (2000), Richtlijnen voor de jaarverslaggeving Jaareditie 2000, Kluwer: Deventer.

Scott, W.R. (1997), Financial Accounting Theory, Prentice Hall: New Jersey.

NOTEN

1 Art. 2:389 lid 6 BW: De rechtspersoon moet een reserve aanhouden ter hoogte van zijn aandeel in de resultaten uit de deelnemingen sedert de eerste waardering overeenkomstig lid 2 (waardering op basis van nettovermogenswaarde: HL/SB) of lid 3 (een andere waardering overeenkomstig deze titel bepaald, indien de rechtspersoon onvoldoende gegevens ter beschikking staan voor de bepaling van de nettovermogenswaarde: $\mathrm{HL} / \mathrm{SB}$ ), verminderd met de uitkeringen waarop sedertdien tot het vaststellen van zijn jaarrekening recht heeft verkregen; uitkeringen waarvan hij zonder beperking ontvangst in Nederland kan bewerkstelli- gen, mogen eveneens in mindering worden gebracht. Deze reserve kan in kapitaal worden omgezet. Onder de in dit lid bedoelde uitkeringen worden niet begrepen uitkeringen in aandelen.

Art. 2:390 lid 1: De rechtspersoon die een actief herwaardeert op een hoger bedrag, neemt op de balans een herwaarderingsreserve op ter grootte van het verschil tussen de boekwaarde van voor en na de herwaardering.

2 Overigens is ook het boekresultaat bij verkoop feitelijk niet in de desbetreffende periode ontstaan.

3 Gucci is een AEX-onderneming die volgens IASregels rapporteert en is opgenomen in de categorie ondernemingen die volgens de regels van het IASC rapporteren. Libertel is een Midkap-onderneming die volgens de regels van het IASC rapporteert.

4 Hierop is één uitzondering. Zie RJ 120.930, waarin wordt weergegeven dat het saldo van de niet aan de moedermaatschappij uitgekeerde, maar bij de moedermaatschappij wel als winst verantwoorde 
bedragen uit deelnemingen over boekjaren die zijn aangevangen vóór 1 januari 1984 niet als een wettelijke reserve in de jaarrekening wordt aangemerkt.

Dit saldo kan onder overige reserves zijn begrepen. Voorzover deze ingehouden winst bij buitenlandse deelnemingen is aangehouden, worden de daaruit ontstane omrekeningsverschillen evenmin als een wettelijke reserve in de enkelvoudige jaarrekening aangemerkt.

5 Hierdoor wordt het aantal verschillen tussen het vermogen en resultaat volgens Nederlandse verslaggevingregels en het vermogen en resultaat volgens Amerikaanse verslaggevingregels voor deze ondernemingen gemitigeerd. 